\title{
Content of Total Polyphenols in Biodynamic Organic Acid Lime (Citrus latifolia Tanaka) Clarified by Microfiltration
}

\author{
Daniela Soares Viana, Lucia Maria Jaeger de Carvalho, \\ Ediane Maria Gomes Ribeiro and Gisela Maria Dellamora Ortiz \\ Federal University of Rio de Janeiro, \\ Brazil
}

\section{Introduction}

The main citrus producing countries according to FAO (2008) are China, Brazil and the United States, followed by Mexico, Spain and Italy. However, by species, Brazil is the first world producer of oranges and lemons by conventional tillage, followed by the United States, while China stands out in the production of tangerines.

In Brazil, the acid lime cv. Tahiti (Citrus latifolia Tanaka), also known as Tahiti lemon, is regarded as one of the commercially most important citric fruits, occupying over 30,000 hectares of cultivated area (Fig.1) (Barros, 1986).

The acid lime is used raw or in the form of juice, especially as an ingredient in the composition of blends to enhance the flavor of beverages (FAO, 2008).

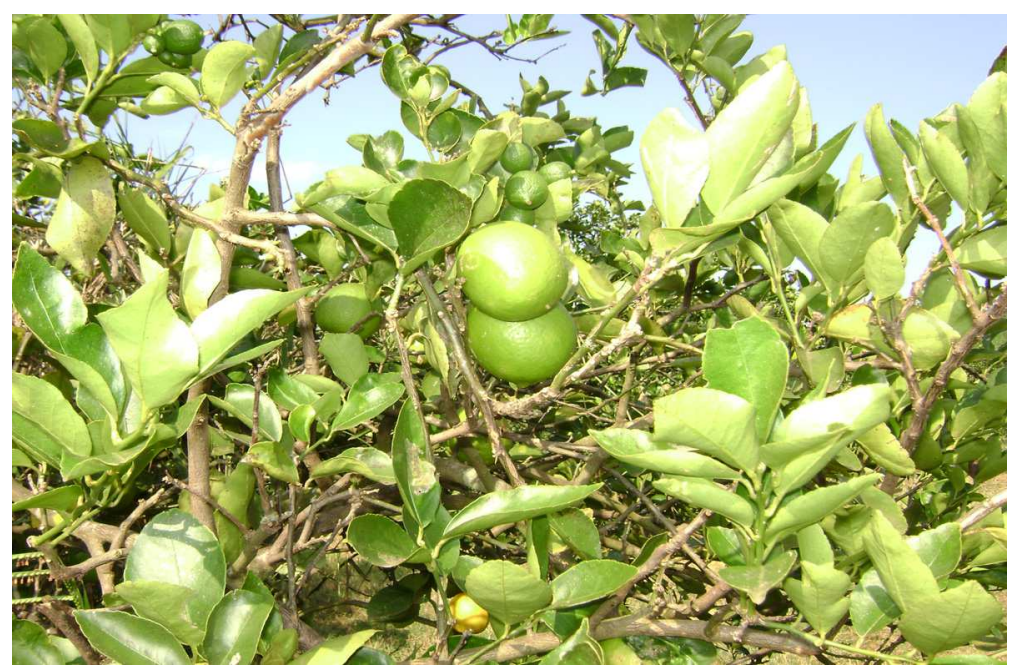

Fig. 1. Leaves and fruits of Citrus latifolia Tanaka, cv. Tahiti (Bom Jesus Farm, São Paulo, July, 2009). 
According to the Secretary of Agricultural Protection (SAP, 1999), the organic system adopts technologies that optimize natural resources, including ecological, biodynamic, natural, sustainable, regenerative, organic and agroecological crops.

So far, the most accurate and reliable system that allows the consumer to determine if a food has been produced by organic or biodynamic organic cultivation is the quality seal provided by national and international entities, such as the Biodynamic Institute (IBD), an organization established in 1991 that develops certification of organic and biodynamic products (Darolt, 2003).

The organic quality seal is an indication that the food was produced and processed in accordance with the guidelines and standards of organic farming, resulting in a positive agronomic quality when compared to conventionally grown food, along with safety and reliability for the consumers that the products have not been subjected to ionizing radiation and have no transgenic or genetically modified organisms (GMOs) in their composition. Therefore, cultivation (without pesticides, fertilizers or chemicals) plus the quality certificate of the Biodynamic Institute (IBD) characterize biodynamic agriculture (IBD, 2009; Darolt, 2003).

The citrus flavor and aroma are pleasant, and in its composition are essential nutrients and micronutrients such as vitamins and minerals, and fiber (Pellegrini et al., 2003; Morton et al., 2000). Vitamin C and phenolic compounds present in acid lime have the ability to capture free radicals, having an important role in its antioxidant activity (Dhuique-Mayer, 2005; Harbone \& Williams, 2000).

Polyphenols are a heterogeneous group, composed of several classes of substances with antioxidant properties that are found in different foods and drinks. Typical compounds that possess antioxidant activity include phenols, phenolic acids and their derivatives, carotenoids, flavonoids (anthocyanins and anthoxantins), tocopherols, phospholipids, amino acids, phytic acid, ascorbic acid and sterols (Roesler et al., 2008).

The first studies on determination of total phenolics were published by Folin \& Ciocalteau (1927), Swain \& Hillis (1959), Singleton \& Rossi (1965), and Fantozzi \& Montedoro (1978). Different methods can be employed to determine the total content of phenolic compounds in foods and plants. The most utilized procedures employ the Folin-Ciocalteau reagent, in which the mixture of phosphowolframic and phosphomolybdic acids, in alkaline media, is reduced by oxidizing phenolic compounds, giving rise to blue wolframium $\left(\mathrm{W}_{8} \mathrm{O}_{23}\right)$ and molybdenum $\left(\mathrm{Mo}_{8} \mathrm{O}_{23}\right)$ oxides (Mirsaeedghazi et al, 2010; Mezadri et al, 2008; Kuskoski et al., 2006).

Some citric fruits such as acerola, orange and lemon contain high concentrations of ascorbic acid, while certain flavonoids such as anthocyanins, flavonols and flavones predominate in strawberry, mulberry and açaí (Cordenunsi et al., 2005; Pozo-Insfran et al., 2004; Assis et al., 2001).

Jardini \& Mancini-Filho (2007) evaluated antioxidant activity of different extracts from the pulp and seeds of rum, and found that the fruit showed high antioxidant activity due to the presence of phenolic and reducing compounds. Water extracts from the pulp and seeds were the most effective regarding antioxidant activity.

Santos et al. (2008) showed that anthocyanins and total phenolics had a positive and significant correlation with the high antioxidant capacity of açaí pulps.

Beneficial health effects, especially a significant decrease on the incidence of chronic and degenerative deseases, have been attributed to ascorbic acid and phenolic constituents of fruits, vegetables, cereals, tea and wine. Epidemiological, clinical and in vitro studies indicate relationships between dietary polyphenols and certain biological effects, such as 
antioxidant, anti-inflammatory, antimicrobial and anticancer activities (Rodrigo et al, 2011; Beer et al, 2005).

The physiological role of phenolic compounds can be more easily understood if one takes into account that in vitro the antioxidant capacity of these substances is related not only to their chemical structures, but also depends upon the type and polarity of the solvent used for the extraction, the isolation process and purity of the compounds, as well as on the substrate to be protected by the antioxidant, and if an aqueous or lipophylic assay system is to be used (Giada, 2005).

Ultrafiltration (UF) and microfiltration (MF) processes have been used by food industries for the clarification, concentration, and cold sterilization of liquids, producing food without chemical additives, with low power consumption, providing alternative products with nutritional quality and agreeable flavor (Carvalho et al., 2008; Koroknai et al., 2008; Cassano et al., 2004; Girard, \& Fukumoto, 2000).

Investigation of the nutritional and sensory post-process quality is required to fulfill the needs of the consumer market for clarified juices, because several substances with nutritional value such as vitamins and minerals, among others, cannot be recovered in the clarified juice or even be retained in the concentrated pulp, or on the surface or inside the membrane pores after UF and MF of juices, with or without prior enzymatic treatment (Koroknai et al., 2008; Cianci et al., 2005; Carvalho et al., 1998).

As well as any other industrial food processing technology, membrane separation processes have several advantages and disadvantages (Habert et al., 2003). The most important drawback is "fouling", a key event in UF and MF processes that can affect economic and commercial viability of a system, since it reduces productivity and useful life of the membrane (Nilsson, 1990). Advantages of membrane processes are increased yields of clarified juices, possibility of operation in one step, lower operational time, operation at room temperature (avoiding food degradation), simple and fast cleaning system, as well as preservation of nutritional and sensory characteristics of foods (Castro et al., 2007; Vaillant et al., 2001).

The aim of this study was to determine the total polyphenol content in biodynamic organic acid lime juice clarified by membrane processes of microfiltration.

\section{Material and methods}

\subsection{Materials}

A total of $113 \mathrm{~kg}$ of biodynamic organic acid lime (Citrus latifolia Tanaka), cultivar Tahiti, 2009 crop, (certified by IBD/IFOAM - Federación Internacional de Movimientos de Agricultura Orgánica) and $58.40 \mathrm{~kg}$ of conventionally cultivated acid lime, 2009 crop, were supplied by Bom Jesus Farm, located in Santa Rita do Passa Quatro, São Paulo, Brazil.

After selection, whole, non-injured fruits were weighed and sanitized by immersion in chlorinated water (100 ppm for $10 \mathrm{~min}$.) and washed. The juice was extracted in a semiindustrial multiprocessor (Konik, Class 700 model, São Paulo, Brazil), sieved, packed in PVC containers and stored at $-15^{\circ} \mathrm{C}$, until processing and analyses.

\subsection{Water permeability and juice recovery (\%)}

Before each MF process, the membrane water permeability was measured at transmembrane pressures of $0.5,1.0$ and 2.0 Bar, respectively, to verify its recovery, according to the following formula: 


$$
\operatorname{Flux}\left({\mathrm{L} . \mathrm{m}^{2}}^{2} \cdot \mathrm{h}\right)=\frac{(\mathrm{L} / \mathrm{h}) \times \mathrm{P}(\text { Bar })}{0.05 \mathrm{~m}^{2}}
$$

Where: $0.05 \mathrm{~m}^{2}=$ total membrane area; $\mathrm{P}=$ applied transmembrane pressure

The water permeability (L.m².h) was measured with a chronometer, at 10 minutes intervals. Cleanup procedures (alkaline and chlorine-alkaline) were performed before and after each process, aiming to recover water permeability of the membrane.

Membrane alkaline cleaning was performed by adding $80 \mathrm{~mL}$ of a $\mathrm{NaOH}$ solution (Tedia, Rio de Janeiro, Brazil) (1N/pH 11) to $10 \mathrm{~L}$ of distilled water at $40{ }^{\circ} \mathrm{C}$, and re-circulating the solution in the system for 30 minutes. The solution was then discarded, using $80 \mathrm{~L}$ of distilled water. Chlorine-alkaline-cleaning was performed by using $40 \mathrm{~mL}$ of $\mathrm{NaOH}$ $(1 \mathrm{~N} / \mathrm{pH} 11)$ and $130 \mathrm{~mL}$ of $\mathrm{NaClO}$ (Tedia, Rio de Janeiro, Brazil) (6\% sodium hypochloride) diluted in $10 \mathrm{~L}$ of distilled water at $40{ }^{\circ} \mathrm{C}$, with recirculation in the system for 30 minutes, followed by washing with $80 \mathrm{~L}$ distilled water. After each cleanup, $\mathrm{pH}$ was checked.

\subsection{Membrane processes}

\subsubsection{Pressure optimization}

The juices were clarified in a PROTOSEP IV system (Koch Membrane Systems Inc., Massachusetts, USA) using a $0.3 \mu \mathrm{m}$ (mean pore diameter) polyethersulfone membrane.

For optimization of the best transmembrane pressure to be applied, $8.0 \mathrm{~L}$ of conventional acid lime juice was used, operating at 0.5, 1.0 and 2.0 Bar, for 60 minutes.

For flux calculation, the volume of the clarified juice was measured each 5 minutes. The best fluxes were obtained at 0.5 Bar TMP, which was used for all the processes, in triplicate.

\subsection{Total polyphenol content}

The whole and clarified acid lime juices were previously lyophilized in a Labconco Lyophilizer (model 75223, Kansas City, Missouri, USA) at $-40^{\circ} \mathrm{C}$, under vacum $\left(<200 \times 10^{-3}\right.$ mBar), for 18 hours.

The Folin-Ciocalteau method (Folin \& Ciocalteau, 1927; Singleton \& Rossi, 1965) was used for quantification of the total polyphenol in the juices. After reaction with the FolinCiocalteau reagent (2N) (Sigma Aldrich, Steinhem, Germany), absorbance was measured at $760 \mathrm{~nm}(\lambda \max =765 \mathrm{~nm})$ using a UV- vis spectrophotometer (Shimadzu, model 1240, Kyoto, Japan). The amount of polyphenols was calculated from a standard curve of gallic acid (MP Biomedicals, Ilkirch, France). The results were expressed as $\mathrm{mg}$ of gallic acid equivalents (GAE)/ $\mathrm{mL}$ of juice sample (Andrade et al., 2007).

\subsection{Statistical analysis}

Statistical analysis was performed using one-way ANOVA and mean values were compared applying Duncan's multiple range tests using Minitab Microsoft Excel. Trends were considered significant when means of compared sets differed at $P<0.05$.

\section{Results and discussion}

\subsection{Conventional lime juices (CLJ) and biodynamic organic lime juices (BLJ) yields}

The CLJ and BLJ yielded 52.60 and $44.65 \%$, respectively, in accordance with the minimum yield of $42 \%$ recommended by Swisher \& Swisher (2000) for citric juices. On the other hand, CLJ yield was significantly higher than that of BLJ $(P<0.05)$, possibly due to the higher 
percentage of peels in the BLJ samples. However, a yield of $47 \%$ was previously reported by Pedrão et al. (1999) for conventional lime juice, cv. Tahiti. Other factors may affect juice yield such as crops with high concentrations of nitrogen and potassium, leading to increased peel thickness, as well as relative humidity, and ambient temperature (Chitarra et al., 1990).

The maturity stage of the fruit also influences the yields of acid lime juice that have been observed, ranging from $55.60 \%$ in green fruit and 59.40\% in ripe fruit (Ziena, 2000).

\subsection{Water permeability and permeate fluxes}

Mean water permeability flux was $1,241.95 \mathrm{~L} . \mathrm{m}^{2} . \mathrm{h}( \pm 0.48)$ in the three processes using the $0.3 \mu \mathrm{m}$ membrane.

In order to determine the best operating transmembrane pressure for all MF processes, $8.0 \mathrm{~L}$ of CLJ were initially used in the feed, resulting in $6.0 \mathrm{~L}(75 \%)$ of clarified juice. The mean fluxes obtained at transmembrane pressures of $0.5,1.0$ and 2.0 bar were $49 ; 47$ and $35 \mathrm{~L}_{\mathrm{m}} \mathrm{m}^{2} . \mathrm{h}$, respectively (Fig.2). A slight difference was observed between the fluxes at the applied transmembrane pressures during the first twenty minutes of the process, but after this time there was a significant flux decline for processes operated at 1.0 and 2.0 Bar, demonstrating that concentration polarization was the result of polarization on the membrane surface and/or fouling, providing a decrease in the clarified juice flux over time (60 minutes) in all cases, which was more pronounced at 2.0 Bar. For both UF and MF processes, flux decline is high even when the water permeability of the membrane is completely recovered by washing (Oliveira et al., 2006).

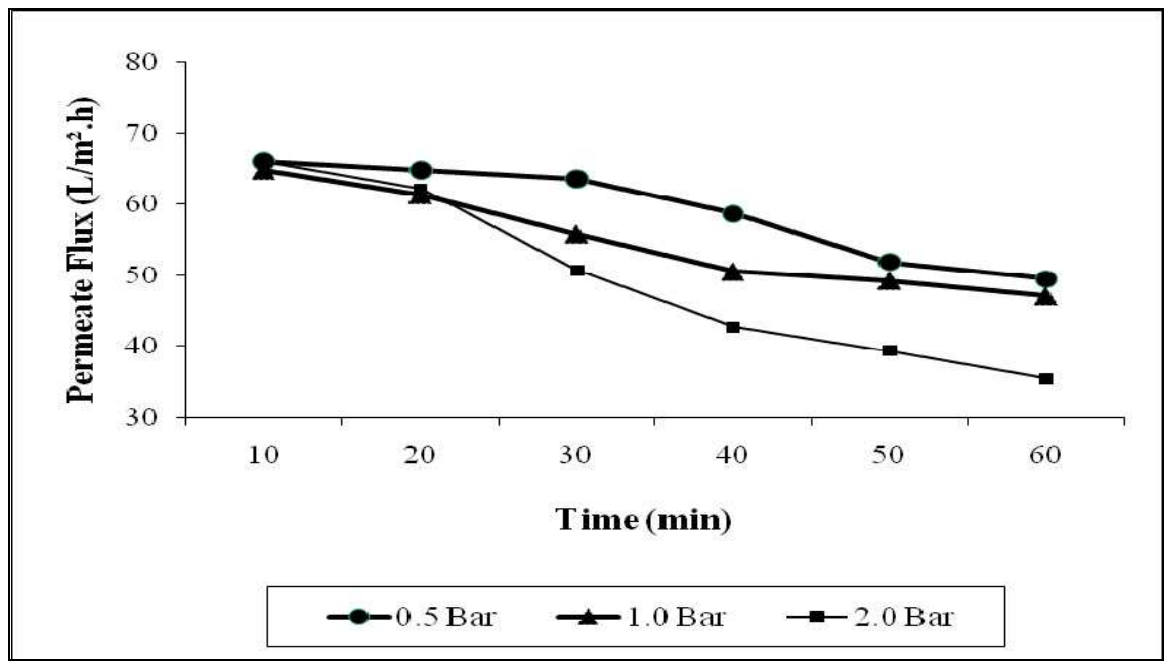

Fig. 2. Effect of process mechanism on the permeate flux at 0.5, 1.0 and 2.0 Bar transmembrane pressures with conventional lime juice.

Thus a 0.5 Bar transmembrane pressure for 60 minutes was adopted to process BLJ by MF, resulting in a mean volume of $6.0 \mathrm{~L}$ of clarified juice from a $8.15 \mathrm{~L}$ feed and yields of 73,76 and $54 \%$ of clarified juice in the first, second and third processes, respectively (Fig. 3). In the first and third process, after the first 20 minutes there was a decrease in the flux that declined gradually declined until the end of the process, probably due to fouling. 


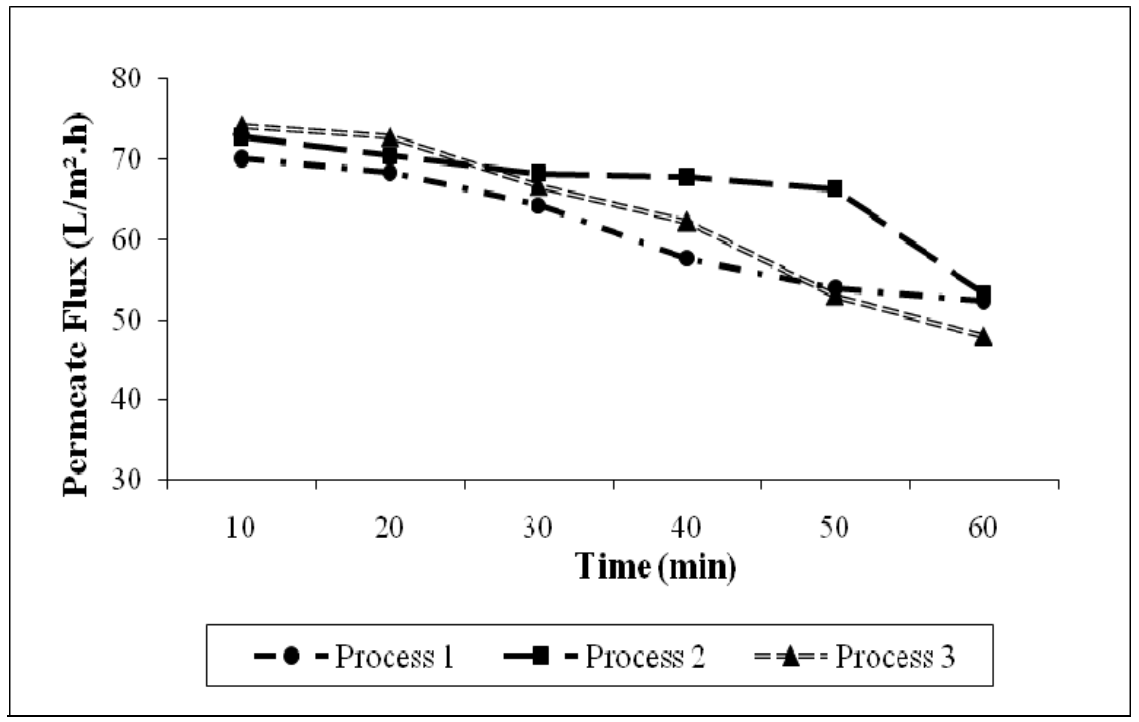

Fig. 3. Effect of process mechanism on the permeate flux at 0.5 Bar with biodynamic lime juice.

MF processes have been employed to clarify apple (Onsekizoglu et al., 2010), orange and kiwi juices (Galaverna et al., 2008), resulting in the same behavior. The processes presented mean fluxes of $75 \mathrm{~L} . \mathrm{m}^{2} . \mathrm{h}$, with a progressive and constant decrease until the end (50 L.m².h). Kozák et al. (2006) and De Paula et al. (2004) using a $0.3 \mu \mathrm{m}$ tubular membrane (polyesthersulphone) at 0.5 Bar transmembrane pressure in the clarification of strawberry and passion fruit juices, observed higher mean flux reductions of clarified juice $(53 \%$ and $56 \%$, respectively). Concentration polarization causes the initial decrease in permeate flux and "fouling" results from accumulation of material on the membrane surface reducing flux along the process time.

A different behavior was observed for clarification of pomegranate juice by MF, using hydrophilic mixed cellulose esters flat membranes (Plate and frame system - $0.22 \mu \mathrm{m}$ ), where the flux decreased rapidly in the early stage (10 minutes - 5.0 L.m $\left.{ }^{2} . \mathrm{h}\right)$, remaining constant until the end (Mirsaeedghazi et al., 2010).

Moreover, Yasan et al. (2007) clarified pasteurized apple juice, with prior enzymatic treatment, using a $0.2 \mu \mathrm{m}$ polyethersulfone flat membrane (Plate and Frame system) obtaining higher than $60 \mathrm{~L} . \mathrm{m}^{2} . \mathrm{h}$ fluxes at 2.0 Bar.

Laorko et al. (2010) used 0.1 and $0.2 \mu \mathrm{m}$ polysulphone hollow fiber membranes at $1.0 \mathrm{Bar}$ in the clarification of hydrolyzed pineapple juice, obtaining fluxes of 24.2 and 22.0 L.m².h., respectively. However, it was noticed that the systems used by the aforementioned authors, especially those using flat and sheet membranes, promote faster fouling formation.

Carvalho et al. (2008) obtained a mean flux of 31.37 L.m².h in clarification by MF of non hydrolyzed pineapple juice, using a $0.3 \mu \mathrm{m}$ tubular polyethersulfone membrane at $3.0 \mathrm{Bar}$, while for the UF of the same juice, the mean flux was $17.39 \mathrm{~L} . \mathrm{m}^{2} . \mathrm{h}$, at 6.0 Bar.

The clarified juices in this study presented light green color and a limpid, translucent and very attractive aspect, as expected. MF processes have been employed to clarify apple 
(Onsekizoglu et al., 2010), orange (Galaverna et al., 2008) and kiwi juices (Cassano, Marchio and Drioli, 2007) resulting in similar characteristics.

\subsection{Total polyphenol contents}

The total polyphenol contents of the whole and clarified CL and BL juices were $304 \mathrm{mg} / 100$ $\mathrm{g}, 336 \mathrm{mg} / 100 \mathrm{~g}, 242 \mathrm{mg} / 100 \mathrm{~g}$ and $263 \mathrm{mg} / 100 \mathrm{~g}$, respectively (Fig. 4). It must be emphasized that the gallic acid calibration curve employed to calculate total polyphenols expressed as gallic acid equivalents (GAE) (mg GA/100 g sample) showed a determination coefficient $\left(R^{2}\right)$ of 0.9967 , proving a positive correlation $(R=0.9983)($ Fig. 5).

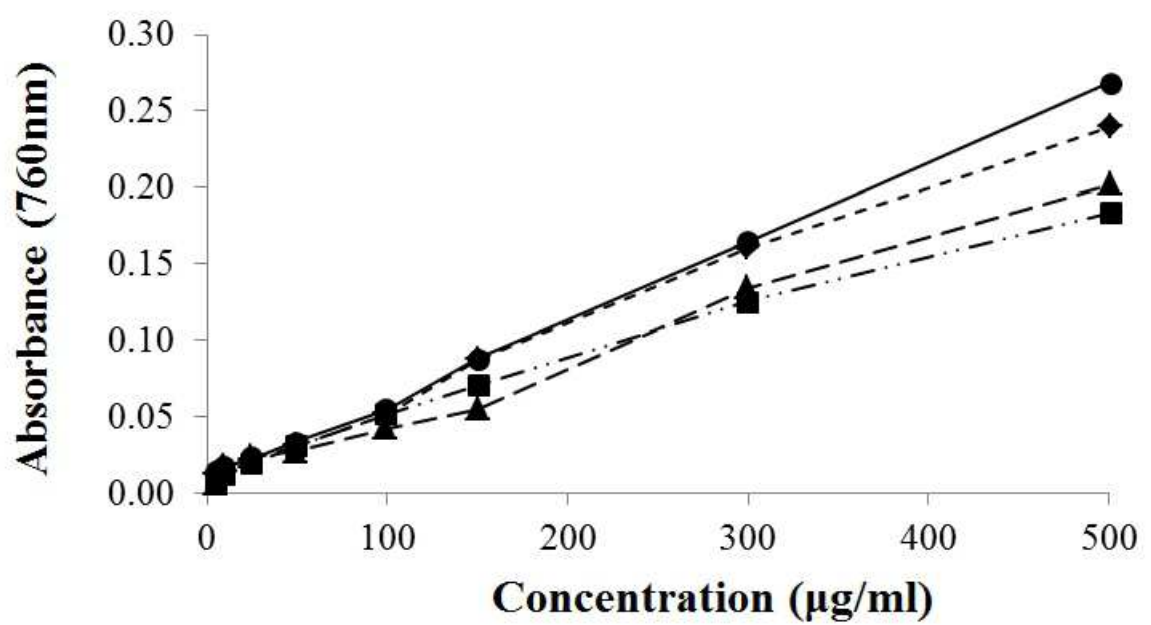

$$
--- \text { CLJ }- \text { CLJ 0.5 Bar } \multimap \text { BLJ }-\star-\text { BLJ } 0.5 \text { Bar }
$$

Fig. 4. Total polyphenol contents in conventional lime (CLJ) and biodynamic lime (BLJ) whole and clarified juices at 0.5 Bar.

Total polyphenols in fruits and juices of fruits of different origins (tropical and exotic) have been investigated for their antioxidant activity. Kuskoski et al. (2005 and 2006) found contents of $897.60,229.60,580.10,544.90,136.80$ and $132.10 \mathrm{mg} \mathrm{GA} / 100$ g, respectively, in extracts of baguaçu and jambolão, acerola, mango, açaí and strawberry pulps. Lower total polyphenol contents were found for jambolão, açaí and strawberry extracts (whole juices) than found in the present study for the whole and clarified acid lime juices. Cavalcante et al. (2006) found total polyphenol contents of $119 \mathrm{mg} \mathrm{GA} / 100 \mathrm{~g}$, in the cashew juice, while Mondello et al. (2000) obtained $217 \mathrm{mg} \mathrm{GA} / 100 \mathrm{~g}$ in orange juice, $145 \mathrm{mg}$ GA/100 $\mathrm{g}$ in caqui, and $134 \mathrm{mg}$ GA/100 $\mathrm{g}$ in pineapple, and Gorinstein et al. (1999) found $164 \mathrm{mg}$ GA/100 g in mango.

However, much higher levels were reported by Vargas et al. (2008) in red grapes (508.4 mg GA/100 g) and white grapes (487.3 mg GA/100 g) recognized as rich in anthocyanins. Rapisarda et al. (2008) also found higher levels of polyphenols in orange juices $(507.01 \mathrm{mg}$ $\mathrm{GA} / 100 \mathrm{~g})$. 

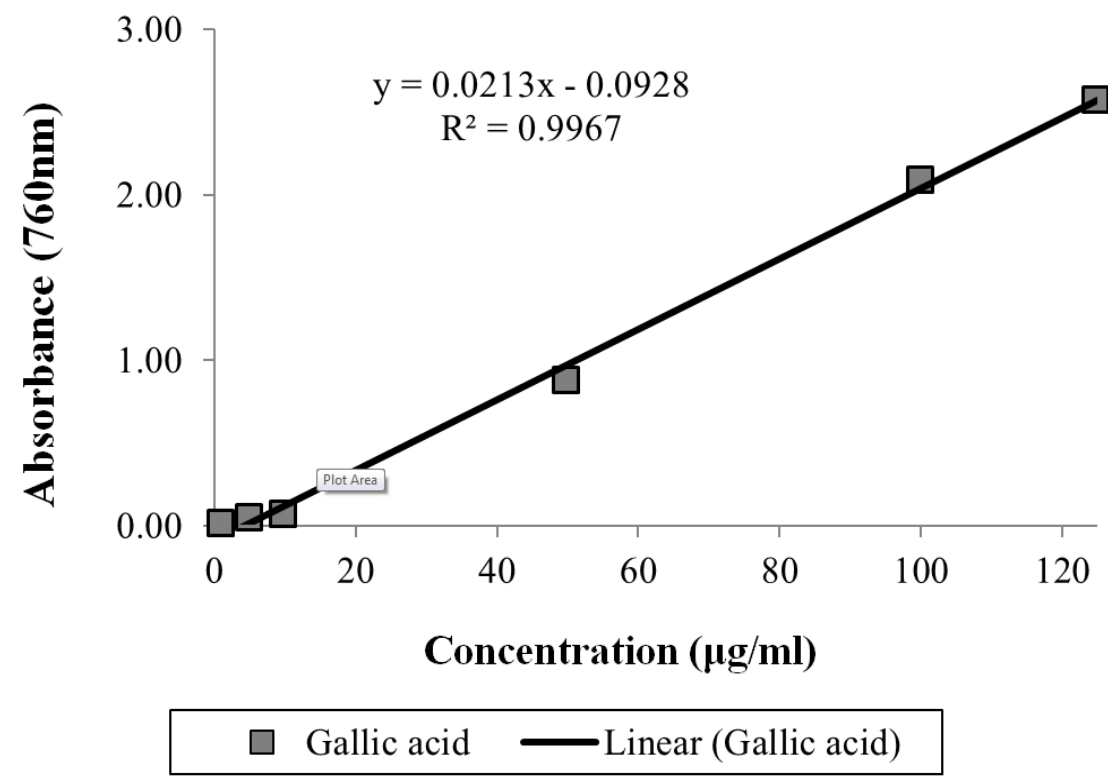

Fig. 5. Calibration curve of gallic acid.

\section{Conclusions}

The MF process recovered $78-79 \%$ of total polyphenols in the whole and clarified juices. Although the antioxidant activity and total polyphenols have been preserved in acid lime juices of both crops, after the MF process, the use of raw materials initially richer in total polyphenols than acid lime is recommended in order to assure a higher content of these compounds in the clarified juice. Studies are being conducted by this research group aiming to compare the different methods for determination of antioxidant activity in whole and clarified juices, since to this moment no official standard method is available.

\section{Acknowledgments}

We wish to thank the Fundação Carlos Chagas de Amparo à Pesquisa do Estado do Rio de Janeiro/FAPERJ for financial support to the project and the granting of scientific initiation scholarships during its development. The authors are also grateful to $\mathrm{CNPq}$ for financial support and the Instituto Nacional de Ciência e Tecnologia para a Inovação Farmacêutica (INCT_if) for support.

\section{References}

Andrade, C.A., Costa, C.K., Bora, K., Miguel, M.D., Miguel, O.G., \& Kerber, V.A. (2007). Determination of phenolic content and antioxidant activity evaluation of Acacia podalyriifolia A. Cunn. Ex G. Don., Leguminosae-mimosoideae. Brazilian Journal of Pharmacognosy, v. 17, n. 2, 231-235. 
Assis, S.A.; Lima, D.C.; Oliveira, O.M.M.F. (2001). Activity of pectinmethylesterase, pectin content and vitamin $\mathrm{C}$ in acerola fruit at various stages of fruit development. Food Chemistry, v. 74, p. 133-137.

Barros, C.B. (1986). Óleos essenciais cítricos do Brasil. 2 ed. Revisão Atualizada, Fundação Cargill, Campinas, 45p.

Beer, D.; Joubert, E.; Gelderblom, W.C.A.; Manley, M. (2005). Antioxidant activity of South African red and white cultivar wines and selected phenolic compound: I vitro inhibition of microsomal lipid peroxidation. Food Chemistry, v. 90, p. 569-577.

Carvalho, L.M.J., Silva, C.A.B., Pierucci, \& A.P.T.R. (1998). Clarification of pineapple juice (Ananas comosus L. Merril) by ultrafiltration and microfiltration: physicochemical evaluation of clarified juices, soft drink formulation, and sensorial evaluation. Journal of Agricultural and Food Chemistry, v. 46, n. 6, p. 2185-2189.

Carvalho, L.M.J., Castro, I.M., \& Silva, C.A.B. (2008). A study of retention of sugars in the process of clarification of pineapple juice (Ananas comosus, L.Merril) y micro and ultrafiltration. Journal of Food Engineering, v. 87, p. 447 - 454.

Cassano, A., Jiao, B., \& Drioli, E. (2004). Production of concentrated kiwifruit juice by integrated membrane process. Food Research International, v. 37, p. 139-148,

Cassano, A., Marchio, M., \& Drioli, E. (2007). Clarification of blood orange juice by ultrafiltration: analyses of operating parameters, membrane fouling and juice quality. Desalination, v. 212, p. 15-27.

Castro, T.R.; Abreu, F.A.P.; Carioca, J.O.B. (2007). Obtaining clarified cashew juice (Anacardium occidentali, L) using membrane separation processes. Revista Ciência Agronômica, v. 38, n. 2, p. 164-168.

Cavalcante, A.A.C.M., Leite, A.S., Salvador, M., \& Rubensam, G., \& Henriques, J.A.P. (2006). Phenolic compounds, carotenoids and vitamin $\mathrm{C}$ in antioxidant activity of cashew juice and cajuína. I CONEPI.

CHITARRA, M. I. F., CHITARRA, A. B. (1990). Post-harvest fruits abd vegetable: physiology and handling. Lavras, MG: FAEP, 230p.

Cianci, F.C., Silva, L.F.M., Cabral, L.M.C., \& Matta, V.M. (2005). Clarification and concentration of cashew juice by membrane processes. Ciência e Tecnologia de Alimentos, v. 12, p. 579-583.

Cordenunsi, B.R.; Genovese, M.I.; Nascimento, J.R.O.; Hassimotto, N.M.A.; Santos, R.J.; Lajolo, F.M. (2005). Effects of temperature on the chemical composition and antioxidant activity of three strawberry cultivars. Food Chemistry, v. 91, p. 113-121.

Darolt, M.R. (2003). Comparison between the quality of organic and conventional food. In: Organic Food: production, technology and certification. Stringheta \& Muniz. Editora UFV, Viçosa, p. 289-312.

De Paula, M.J., Lissi, C.V., Monteiro, B.F., \& Venildes, H.R. (2004). Improvement in the efficiency of clarification of passion fruit juice by a combination of microfiltration and enzymatic processes. Ciência e Tecnologia de Alimentos, v. 22, n. 2, p. 311-324.

Dhuique-Mayer, C.; Caris-Veyrat, C.; Ollitrault, P.; Curk, F.; Amiot, M.J. (2005). Varietal and interspecific influence on micronutrient contents in citrus from the Mediterranean area. Journal of Agricultural and Food Chemistry, v. 53, p. 2140-2145.

Fantozzi, P.; Montedoro, G. (1978). Dosage des composés phénoliques dans les drupes d'olives récoltés à différents stades de maturation. Industries Alimentaires v. 17, p. 1335-1339. 
FAO - FOOD AGRICULTURE ORGANIZATION (2008). FAOSTAT Statistics database, Agriculture, Rome, Italy, p. 52-58.

Folin, C., \& Ciocalteau, V. (1927). Tyrosine and tryptophan determination in proteins. Journal of Biology Chemistry, v. 73, p. 627-650.

Galaverna, G., Silvestro, G., Cassano, A., Sforza, S., Dossena, A., Drioli, E., \& Marchelli, R. (2008). New integrated membrane process for the production of concentrated blood orange juice: effect on bioactive compounds and antioxidant activity. Food Chemistry, v. 106, p. 1021-1030.

Giada, M.L.R. (2005). Evaluation of the antioxidant capacity of phenolic compounds from the cotyledon of sunflower seeds (Helianthus annuus L.) rajada. Doctoral Thesis (Food Science) - Food and Experimental Nutrition Departament, Universidade de São Paulo (USP), São Paulo, Brazil. 206 p.

Girard, B., \& Fukumoto, L.R. (2000). Apple juice clarification using microfiltration and ultrafiltration polymeric membranes. Lebensmittel-Wissenscheft und Technologie, v. 32, n. 5, p. 290-298.

Gorinstein, S., Zemser, M., Haruenkit, R., Chuthakorn, R., Grauer, F., Martín-Belloso, O., Trakhtenberg, S. (1999). Comparative content of total polyphenols and dietary fiber in tropical fruits and persimmon. Journal of Nutritional Biochemistry, v. 10, p. 367371.

Habert, A.C.; Borges, C.P.; Nobrega, R. (2003). Membrane separation processes. Chemical Engineering Program. COPPE/UFRJ.

Harborne, J.B.; Williams, C.A. (2000). Advances in flavonoid research since 1992. Phytochemistry, v. 52, p. 481-504.

IBD - INSTITUTO BIODINÂMICO (2009). Guidelines for the organic quality standard.. 17th Edition, Doc. 812, Botucatu, São Paulo.

IFOAM - FEDERACIÓN INTERNACIONAL DE MOVIMIENTOS DE AGRICULTURA ORGÂNICA (2002) - IFOAM Basic Standards for organic production and processing.

Jardini, F.A. ; Mancini-Filho, J. Evaluation of antioxidant activity in different extracts of the pulp and seeds of the pomagranate (Punica granatum, L.) (2007). Brazilian Journal of Pharmaceutical Sciences, v. 43, n.1, p. 138-147.

Koroknai, B., Csanádi, Z., Gubcza, L., \& Bélafi-Bakó, K. (2008). Preservation of antioxidant capacity and flux enhancement in concentration of red fruit juices by membrane processes. Desalination, v. 228, p. 295-301.

Kozák, A., Rektor, A., Vatai, G. (2006). Integrated largescale membrane process for producing concentrated strawberry fruit juices. Desalination, v. 200, p. 540-542.

Kuskoski, E.M., Asuero, A.G., Troncoso, A.M., Mancini-Filho, J., \& Fett, R. (2005). Application of several chemical methods to determine antioxidant activity in pulp. Ciência e Tecnologia de Alimentos, v. 25, n. 4, p. 726-732.

Kuskoski, E.M., Asuero, A.G., Morales, M.T., \& Fett, R. (2006). Tropical and wild fruits and frozen pulps: antioxidant activity, polyphenols and anthocyanins. Ciência Rural, Santa Maria v. 36, p. 1283-1287.

Laorko, A.; Li, Z.; Tongchitpakdee, S.; Chantachum, S.; Youravong, W. (2010). Effect of membrane property and operating conditions on phytochemical properties and permeate flux during clarification of pineapple juice. Journal of Food Engineering, v. 100, p. 514-521. 
Mezadri, T.; Villaño, D.; Fernández-Pachón, M.S.; García-Parrilla, M.C.; Troncoso, A.M. (2008). Antioxidant compounds and antioxidant activity in acerola (Malpighia emarginata DC.) fruits and derivates. Journal of Food Composition and Analysis, v. 21, p. 282-290.

Mirsaeedghazi, H.; Mousavi, S.M.; Djomeh, Z.E.; Rezaei, K.; Aroujalian, A.; Navidbakhsh, M. (2011). Comparison between ultrafiltration and microfiltration in the clarification of pomegranate juice. Journal of Food Processing Engineering. Online ISSN: $1745-4530$

Mondello, L., Cotroneo, A., Errante, G., Dugo, G., \& Dugo, P. (2000). Determination of anthocyanins in blood Orange juices by HPLC analysis. Journal of Pharmaceutical and Biomedical Analysis, v. 23, p. 191-195.

Morton, L.W., Cacetta, R.A., Puddey, I.B., Croft, K.D. (2000). Chemistry and biological effects of dietary phenolic compounds: Relevance to cardiovascular disease. Clinical and Experimental Pharmacology and Phisiology, v. 27, p. 152-159.

Nilsson, L.S. (1990). Protein fouling of UF membrane: Causes and consequences. Journal of Membrane Science, v. 56, p. 13-28.

Oliveira, J. C; Setti-Perdigão P.; Siqueira, K. A. G.; Santos A. C.; Miguel, M. A. L. (2006). Microbiology of orange juice. Ciência e Tecnologia de Alimentos, Campinas, v. 26, p. 241-5.

Onsekizoglu, P., Savas Bahceci, K., \& Jale Acar, M. (2010). Clarification and the concentration of apple juice using membrane processes: A comparative quality assessment. Journal of Membrane Science, v. 26, p. 376-381.

Pedrão, M.R.; Beleia, A.; Modesta, R.C.D.; Prudencio-Ferreira, S.H. (1999). Physical and chenical stability and sensory Tahiti natural lemon juice and sweteneed, frozen. Ciência e Tecnologia de Alimentos, v. 19, n.2, p. 156-162.

Pellegrini, N.; Serafini, M.; Colombi, B.; Del Rio, D. (2003). Total antioxidant capacity of plant foods beverages and oils consumed en Italy assessed by three different in vitro assays. Journal of Nutrition, v. 133, p. 2812-2819.

Pozo-Insfran, D.D.; Brenes, C.H.; Talcott, S.T. (2004). Phytochemical composition and pigment stability of açaí (Euterpe oleraceae Mart.). Journal of Agricultural and Food Chemistry, v. 52, n. 6, p. 1539-1545.

Rapisarda, P., Bianco, M.L., Pannuzzo, P., \& Timpanaro, N. (2008). Effect of cold storage on vitamin $\mathrm{C}$, phenolics and antioxidant activity of Five Orange genotypes (Citrus sinensis L. Osbeck). Postharvest Biology and Technology, v. 49, p. 348-354.

Rodrigo, R., Miranda, A., Vergara, L. (2011). Modulation of endogenous antioxidant system by wine polyphenols in human disease. Clinica Chimica Acta, v. 412, p. 410-424.

Roesler, R., Catharino, R.R.; Malta, L.G.; Eberlin, M.N.; Pastore, G. (2008). Antioxidant activity of Caryocar brasiliense (pequi) and characterization of components by electrospray ionization mass spectrometry. Food Chemistry, v. 110, p. 711-717.

Santos, G.M.; Maia, G.A.; Sousa, P.H.M.; Costa, J.M.C.; Figueiredo, R.W.; Prado, G.M. (2008). Correlation betwen antioxidant activity and bioactive compounds of commercial açaí pulp (Euterpe oleracea Mart). Latin Americal Files Nutrition, v. 58, n. 2, p. 187-192.

SAP - SECRETARY OF AGRICULTURAL PROTECTION. Normative Instruction number 7 of May 17th, (1999). Official Daily of State of May 19th, 1999, Chapter I, 11p. Available on: www.agricultura.gov.br. 
Singleton, V.L.; Rossi, J.A. (1965). Colorimetry of total phenolics with phosphomolybdicphosphotungstic acid reagents. American Journal of Enology and Viticulture, p. 144158.

Swain, T.; Hillis, W.E. (1959). The phenolic constituents of Punnus domestica. I. Quantitative analysis of phenolic constituents. Journal of the Science of Food and Agriculture, v. 10, p. 63-68.

Vaillant, F.; Millan, A.; Dornier, M.; Decloux, M.; Reynes, M. (2001). Strategy for economical optimisation of the clarification of pulpy fruit juices using cross flow microfiltration. Journal of Food Engineering, v. 48, p. 83-90.

Vargas, P.N., Hoelzel, S.C., \& Rosa, C.S. (2008). Determination of total polyphenols content and antioxidant activity in commercial grape juices. Alimentos e Nutrição, v. 19, n. 1, p. 11-15.

Yasan, H.; Zhijuan, J.; Shunxin, L. (2007). Effective clarification of apple juice using membrane filtration without enzyme and pasteurization pretreatment. Separation and Purification Technology, v. 57, p. 366-373.

Ziena, H.M.S. (2000). Quality attributes of Bearss Seedless lime (Citrus latifolia Tanaka) juice during storage. Food Chemistry, v.71, p.167-172. 


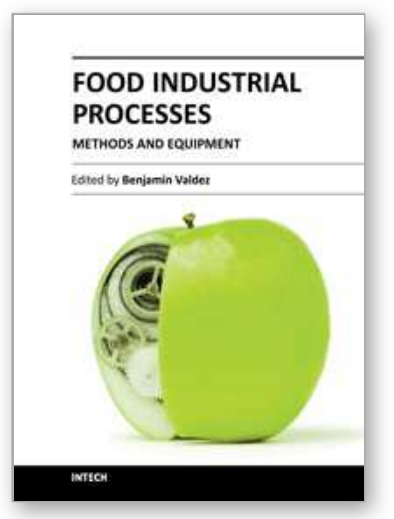

\author{
Food Industrial Processes - Methods and Equipment \\ Edited by Dr. Benjamin Valdez
}

ISBN 978-953-307-905-9

Hard cover, 418 pages

Publisher InTech

Published online 22, February, 2012

Published in print edition February, 2012

The global food industry has the largest number of demanding and knowledgeable consumers: the world population of seven billion inhabitants, since every person eats! This population requires food products that fulfill the high quality standards established by the food industry organizations. Food shortages threaten human health and are aggravated by the disastrous, extreme climatic events such as floods, droughts, fires, storms connected to climate change, global warming and greenhouse gas emissions that modify the environment and, consequently, the production of foods in the agriculture and husbandry sectors. This collection of articles is a timely contribution to issues relating to the food industry. They were selected for use as a primer, an investigation guide and documentation based on modern, scientific and technical references. This volume is therefore appropriate for use by university researchers and practicing food developers and producers. The control of food processing and production is not only discussed in scientific terms; engineering, economic and financial aspects are also considered for the advantage of food industry managers.

\title{
How to reference
}

In order to correctly reference this scholarly work, feel free to copy and paste the following:

Daniela Soares Viana, Lucia Maria Jaeger de Carvalho, Ediane Maria Gomes Ribeiro and Gisela Maria Dellamora Ortiz (2012). Content of Total Polyphenols in Biodynamic Organic Acid Lime (Citrus latifolia Tanaka) Clarified by Microfiltration, Food Industrial Processes - Methods and Equipment, Dr. Benjamin Valdez (Ed.), ISBN: 978-953-307-905-9, InTech, Available from: http://www.intechopen.com/books/food-industrialprocesses-methods-and-equipment/content-of-total-polyphenols-in-biodynamic-organic-acid-lime-citruslatifolia-tanaka-clarified-by-mi

\section{INTECH}

open science | open minds

\section{InTech Europe}

University Campus STeP Ri

Slavka Krautzeka 83/A

51000 Rijeka, Croatia

Phone: +385 (51) 770447

Fax: +385 (51) 686166

www.intechopen.com

\section{InTech China}

Unit 405, Office Block, Hotel Equatorial Shanghai

No.65, Yan An Road (West), Shanghai, 200040, China

中国上海市延安西路65号上海国际贵都大饭店办公楼 405 单元

Phone: +86-21-62489820

Fax: +86-21-62489821 
(C) 2012 The Author(s). Licensee IntechOpen. This is an open access article distributed under the terms of the Creative Commons Attribution 3.0 License, which permits unrestricted use, distribution, and reproduction in any medium, provided the original work is properly cited. 